\title{
TINJAUAN YURIDIS TERHADAP PEMENUHAN HAK-HAK ANAK DI LEMBAGA PEMASYARAKATAN KLAS I A MAKASSAR
}

\author{
OLEH : \\ HERLINA SULAIMAN \\ DOSEN FAKULTAS HUKUM \\ UNIVERSITAS ICHSAN GORONTALO
}

\begin{abstract}
The perpetrator of the criminal act of the child cannot be equated with criminal adults. Therefore it needs more attention in the case of children. However, the child is the successor Nations that should be developed physically and mentally. The purpose of this research is to analyze the role of the Ombudsman in the performance of Marisa Polres versioned as well as analyze constraints are faced by Investigators in Marisa Polres versioned. This type of research is research used empirical research focus i.e. normative on secondary data sources (research libraries). This research uses the main data source i.e. secondary data, backed up with primary data sources. Secondary data is used that is derived from legislation such as the ACT on the criminal justice system of the child, the child protection ACT, Act No. 8 Of 1981 Year Book of the Police Act, Police ACT and some of the literature-literature as well as the results of his research, and books related to the role of the Ombudsman in conducting versioned on criminal act committed by the child. Research results show that Marisa Polres in performing the investigation is a criminal act committed by the child by women and children protection Unit (UPPA). Starting from the stage of investigation, arrest, detention up at the stage of investigation conducted in accordance with the mandate of the ACT on the criminal justice system. Investigators in conducting versioned, get consideration from BAPAS. In addition, the investigators also act as mediator to conduct deliberations involving the child and the parent/guardian, the victim and the parent/guardian, supervisor of community, social professional pekera based on approach restorative. Obstacles faced by Investigators in the conduct of Marisa Polres diversion that is not yet the existence of BAPAS in counties Marisa so complicate investigators to coordinate-in terms of asking for consideration in doing versioned. In addition the party victims sometimes do not want to make peace so that the attempted diversion by Investigators was not achieved.
\end{abstract}

Key Words: Diversion, Crime, Police

\section{A. PENDAHULUAN}

Manusia tidak pernah bisa memilih untuk dilahirkan sebagai dari ras atau etnis tertentu. Adanya perbedaan ras atau etnis tidak dengan sendirinya berarti terdapat 
perbedaan hak dan kewajiban antar kelompok ras atau etnis dalam masyarakat dan negara. Setiap warga negara berhak memperoleh perlakuan yang sama untuk mendapatkan hak-hak sipil, politik, ekonomi, sosial, dan budaya sesuai dengan ketentuan peraturan Perundang-undangan, tanpa membedakan ras dan etnis, dalam pemberian perlindungan terhadap warga negara dari segalah bentuk tindakan diskriminasi ras dan etnis, diperlukan pengawasan yang dilakukan oleh KOMNAS HAM dengan maksud untuk mengevaluasi kebijakan Pemerintah baik pusat maupun daerah yang dilakukan secara berkala atau insedental dengan cara memantau, mencari fakta, menilai guna mencari dan menemukan ada tidaknya diskriminasi ras dan etnis yang ditindak lanjuti dengan rekomendasi sebagaimana telah diatur dalam Undang-Undang Nomor 40 Tahun 2008 tentang penghapusan diskriminasi ras dan etnis.

Hak Asasi yang dimiliki setiap manusia merupakan hak dasar yang bersifat universal dan langgeng yang dilindungi, dihormati, dipertahankan dan tidak boleh diabaikan, dikurangi atau dirampas oleh siapapun, mereka memiliki hak dan kedudukan yang sama sebagai warga negara Indonesia. Adanya persamaan hak yang dimiliki oleh setiap individu bukan hanya ditujukan pada orang dewasa tapi diberlakukan juga bagi anak-anak baik yang sudah lahir maupun anak yang masih berada dalam kandungan Ibunya. Pernyataan ini diperjelas dalam Pasal 1 angka 5 UU No.39 Tahun 1999 tentang Hak Asasi Manusia, pengertian anak adalah setiap manusia yang berumur di bawah 18 tahun dan belum menikah termasuk anak yang masih dalam kandungan apabila hal tersebut adalah demi kepentingannya.

Anak adalah bagian dari genersi muda sebagai salah satu sumber daya manusia yang merupakan potensi dan penerus cita-cita perjuangan bangsa yang memiliki peranan strategis dan mempunyai ciri dan sifat khusus, memerlukan pembinaan dan perlindungan dalam rangka menjamin pertumbuhan dan perkembangan fisik, mental, dan sosial secara utuh, serasi, selaras dan seimbang, karena di dalam diri anak terdapat hak atas kelangsungan hidup, tumbuh, dan berkembang serta berhak atas perlindungan dari kekerasan dan diskriminasi, hal ini dijelaskan dalam Undang-Undang Dasar 1945 perubahan kedua Pasal 28 ayat ( 2 ).

Berhubungan dengan proses perkembangan adalah saat anak menyadari permintaan dan syarat-syarat hidup dalam suatu lingkungan. Meskipun masih dalam 
lingkungan keluarga, batas-batas dalam bentuk disiplin mulai dapat diberikan. Disiplin yang tegas tetapi disertai kasih sayang akan membantu anak dalam perkembangan emosinya. Sebaliknya jika disiplin dilakukan dengan kekerasan yang tidak beralasan dan tanpa kasih sayang, akan menimbulkan keragu-raguan pada diri anak dan anak akan kehilangan kepercayaan diri. Apabila ini terjadi pada dua anak dalam satu keluarga (Seayah/Seibu) secara individual, perkembangan emosinya akan jelas bisa dibedakan.

Pelaksanaan pembinaan dan pemberian perlindungan terhadap anak, diperlukan dukungan baik yang menyangkut kelembagaan maupun perangkat hukum yang lebih mantap dan memadai, oleh karena itu ketentuan mengenai penyelenggaraan pengadilan bagi anak perlu dilakukan secara khusus.

Perkembangan zaman dan teknologi seperti sekarang ini, sering menyebabkan terjadinya pergesaran nilai, norma, budaya dan adat ketimuran, yang tidak dapat kita abaikan, karena membawa pengaruh baik yang positif maupun negatif bagi masyarakat, tak terlepas pula bagi anak.

Kadang kala perilaku anak sering menyimpang dalam perkembangan tingkah lakunya, yangmemperlihatkan gejala perilaku anak menjurus kepada tindak pidana kejahatan, seperti pemerkosaan, pencabulan, pencurian, perkelahian antar pelajar dan lain-lain. Hal ini dapat menyebabkan anak tersebut diharuskan berhadapan dengan proses hukum yang disamakan dengan orang dewasa. Penyimpangan tingkah laku atau perbuatan melanggar hukum yang dilakukan anak, dapat disebabkan oleh berbagai faktor, baik dalam lingkungan anak itu sendiri maupun dari luar, faktor tersebut antara lain dampak negatif perkembangan yang cepat, arus globalisasi dan komunikasi, kemajuan ilmu pengetahuan dan teknologi, serta perubahan cara hidup atau pergeseran nilai-nilai dan norma-norma di masyarakat.

Menyangkut hal di atas mengenai penyimpangan-penyimpangan yang ditimbulkan sang anak, baik penyimpangan berat maupun ringan perlu diberikan perhatian besar, baik dari pihak keluarga, masyarakat, maupun dari pihak pemerintah.

Untuk mencegah terjadinya berbagai penyimpangan maka diperlukan kaidah atau norma yang dapat dijadikan pedoman hidup manusia serta menentukan apa yang 
seharusnya dapat dilakukan oleh manusia dan apa yang tak boleh dilakukannya. Oleh karena itu diperlukan penanganan sejak dini terhadap bahaya-bahaya yang dapat ditimbulkan dari penyimpangan yang dilakukan anak, dan memberikan pengawasan serta pembinaan terhadap anak, baik dari pihak orang tua yang mengawasi perilaku anak-anak secara langsung, serta keikutsertaan atau peran serta dan keterpaduan berbagai pihak, baik masyarakat umum maupun pemerintah khususnya.

Sehubungan dengan itu menganalisis persoalan secara rasional dan mendasar agar dapat dipecahkan sebaik-baiknya dapat juga dilihat dari pendapat Muladi (Djisman Samosir : 1992 :1) yaitu sebagai berikut :

"Pengaruh perubahan sosial sebagai akibat perubahan proses modernisasi mengharuskan setiap orang untuk menganalisis segala sesuatu secara rasional dan mendasar, agar setiap masalah yang timbul di Masyarakat dapat dipecahkan sebaikbaiknya. Demikian juga di dalam usaha mencapai suatu sistem hukum pidana yang mantap, para perencana dan penyelenggara hukum pidana harus memperhitungkan kenyataan-kenyataan kemanusiaan dan sosial, serta mencoba untuk menciptakan prasyarat-prasyarat yang sedapat mungkin jelas dan efisien serta selalu menyesuaikan pada kecenderungan yang menjadi tanda ciri dari suatu masyarakat".

Indonesia yang menganut konsep negara hukum (Rechtstaat) idealnya memposisikan hukum sebagai Panglima untuk menjamin kepastian tata tertib sosial (social order) masyarakat secara objektif dan tampa diskriminasi serta memberikan jaminan perlindungan dan kepastian hukum bagi pelaksanaan hak-hak asasi setiap individu. Hal tersebut menjadi konsekuensi logis dari cita-cita masyarakat Indonesia untuk mewujudkan negara hukum yang demokratis.

Sebagai negara yang merdeka idealnya memiliki suatu perangkat hukum yang sesuai sebagai aspirasi sebagai suatu bangsa yang merdeka. Selain itu perangkat hukum tersebut menjadi aturan main yang terbingkai dalam suatu kodifikasi hukum untuk menjaga agar selaras dengan rasa keadilan yang tumbuh dan berkembang dalam masyarakat yang merupakan persyaratan utama terciptanya masyarakat adil dan makmur dimana melekat padanya perubahan kondisi sosial kultur. 
Karena itu dalam perumusan suatu aturan hokum hendaknya otoritas sosial dalam hal ini pemerintah hendaknya melihat kebutuhan dan keinginan masyarakat apakahproduk hukum yang dilahirkannya telah mengakomodir kepentingan dan keinginanmasyarakat. Sehingga pada akhirnya meminimalisir reaksi-reaksi kontra terhadap terhadap produk hukum yang dilahirkan serta perdebatanperdebatanyangmungkin lahir sebagai impilikasi dari eksistensi produk hukum tersebut.

Adapun implikasi dan eksistensi produk hukum tersebut melahirkan tujuan nasional dalam rangka mewujudkan cita-cita luhur bangsa Indonesia menuju masyarakat yang adil, makmur dan sejahtera yang merata baik secara materiil maupun spritual berdasarkan Pancasila dan Undang-undang Dasar 1945.

Demi mewujudkan cita-cita luhur bangsa yang tertuang dalam Undang-undang Dasar 1945, olehnya itu diperlukan suatu perangkat hukum yang dapat mengayomi masyarakat, terutama dibidang hukum pidana. Hal ini dapat diwujudkan melalui penegakan hukum pidana yang bekerja secara operasional melalui suatu sistem yang disebut sistem peradilan pidana (Criminal justice System).

Salah satu bagian pembangunan nasional adalah pembangunan dibidang hukum, yang dikenal dengan istilah pembaharuan hukum (law reform). Pembaharuan hukum nasional sebagai bagian dari rangkaian pembangunan nasional ini dilakukan secara menyeluruh dan terpadu baik hukum pidana, hukum perdata maupun hukum administrasi, dan meliputi juga hukum formil maupun hukum materielnya.

Sebagai suatu sistem, peradilan pidana mempunyai perangkat struktur atau sub sistem yang harus bekerja secara koheren, koordinatif dan integral agar dapat mencapai efisiensi dan efetivitas yang maksimal.

Subsistem-subsistem ini berupa Kepolisian, Kejaksaan, Pengadilan, Advokat dan Lembaga Pemasyarakatan sebagai Lembaga Pembinaan. Inilah dinamakn struktur hukum (legal structure).

Lembaga Pemasyarakatan (LP) sebagai salah satu subsistem peradilan pidana mempunyai peranan penting dan strategis di dalam penegakan hukum pidana, yang 
semua itu dapat terwujud dalam pelaksanaan pembinaan bagi narapidana dan anak didik pemasyarakatan. Pelaksaanaan pembinaan inilah dikenal dengan nama Pemasyarkatan.

Adanya perubahan sistem dalam Pemasyarakatan,dari Penjara menjadi Pemasyarakatan membawa perubahan yang mendasar. Sebagaimana yang diatur dalam Pasal 1 butir ke-2 Undang-Undang Nomor 12 Tahun 1995 tentang Pemasyarakatan, ditegaskan bahwa Sistem Pemasyarkatan adalah suatu tatanan mengenai arah dan batas, serta cara pembinaan Warga Binaan Pemasyarakatan berdasarkan Pancasila dan dilaksanakan secara terpadu antara pembina, yang dibina, dan masyarakat untuk meningkatkan kualitas Warga Binaan, Pemasyarkatan agar mampu menyadari kesalahan, memperbaiki diri, dan tidak mengulangi kejahatan yang telah dilakukanya, sehinga dapat diterima kembali oleh lingkungan masyarakat, dapat aktif berperan dalam pembangunan, dan dapat bertanggung jawab.(Tolib Effendi, 2013: 163).

\section{B. METODE PENELITIAN}

Metode penelitian yang digunakan dalam penelitian ini adalah metode penelitian Empirik yaitu penelitian yang langsung dilakukan di Lembaga Pemasyarakatan serta bentuk pelaksanaannya di lapangan, bertujuan untuk menjelaskan proses pemenuhan hak-hak bagi Anak Didik Pemasyaratan di Lembaga Pemasyarakatan Klas I Makassar. Sedangkan metode pendekatan yang digunakan adalah yuridis sosiolagis. Tipe penelitian dalam tesis ini bersifat deskriptif, yaitu dengan menganalisa realitas dan implementasi hukum, serta memberikan gambaran tentang fenomena sosial tertentu dan digambarkan secara terperinci, untuk memberikan informasi secara lengkap. Penelitian ini berusaha untuk menggambarkan secara terperinci bagaimana pemenuhan hak-hak Anak Didik Pemasyarakatan pada Lembaga Pemasyarakatan Klas I Makassar yang kemudian menyajikan secara lengkap.

\section{HASIL PENELITIAN DAN PEMBAHASAN}

a. Pemenuhan Hak-Hak Anak Didik Pemasyarakatan di Lembaga Pemasyarakatan Klas I Makassar.

Berdasarkan UU No. 12 Tahun 1995 tentang Pemasyarakatan pasal 1 angka 1 memberikan pengertian mengenai pemasyarakatan. Disebutkan bahwa : 
"Pemasyarakatan adalah kegiatan untuk melakukan pembinaan Warga Binaan Pemasyarakatan berdasarkan sistem, kelembagaan, dan cara pembinaan yang merupakan bagian akhir dari sistem pemidanaan dalam tata peradilan pidana".

Selanjutnya dalam pasal 1 angka 3 di sebutkan lagi :Lembaga Pemasyarakatan yang selanjutnya disebut LAPAS adalah tempat untuk melaksanakan pembinaan Narapidana dan Anak Didik Pemasyarakatan".

Anak yang telah dijatuhkan pidana karena telah melakukan kejahatan akan dibina di Lembaga pemasyarakatan yang kemudian akan berganti status menjadi Anak Didik Pemasyarakatan. Dalam Pasal 1 angka 8 UU No 12 tahun 1995 menjelaskan tentang Anak Didik Pemasyarakatan adalah:

a. Anak Pidana yaitu anak yang berdasarkan putusan pengadilan menjalani pidana di lembaga pemasyarakatan Anak paling lama sampai berumur 18 (delapan belas) tahun;

b. Anak Negara yaitu anak yang berdasarkan putusan pengadilan diserahkan pada negara untuk dididik dan ditempatkan di lembaga pemasyarakatan Anak paling lama sampai berumur 18 (delapan belas) tahun;

c. Anak Sipil yaitu anak yang atas permintaan orang tua atau walinya memperoleh penetapan pengadilan untuk dididik di lembaga pemasyarakatan Anak paling lama sampai berumur 18 (delapan belas) tahun.

Pada saat penulis melakukan penelitian diLembaga Pemasyarakatan Klas I Makassar hanya terdapat anak pidana. Anak negara dan anak sipil tidak ada karena pada umumnya mereka diserahkan kepada dinas sosial (Wawancara dengan Ibu Sira Te'dang Patandean pada tanggal 20 januari 2014).

Senada dengan ibu Sira Te'dang Patandean, Bapak Andi Moh. Hamka juga menjelaskan bahwa alasan tidak adanya anak sipil dan anak negara di Lembaga Pemasyarakatan Klas I Makassar disebabkan seringnya hakim memberikan putusan terhadap anak yang melakukan tindak pidana dengan putusan sebagai anak pidana bukan anak negara dan anak sipil. Hal ini disebabkan karena kasus yang dilakukan oleh anak-anak tersebut tergolong kasus-kasus yang berat. Kalaupun ada putusan yang 
menempatkan anak tersebut menjadi anak sipil atau anak negara, maka anak tersebut langsung diserahkan kepada Dinas Sosial atau dikembalikan kepada orang tuanya.

Dalam pasal 60 ayat (1) UU No. 3 tahun 1997 Tentang Pengadilan Anak disebutkan bahwa : Anak Didik Pemasyarakatan ditempatkan di Lembaga Pemasyarakatan Anak yang harus terpisah dari orang dewasa. Kemudian dalam Pasal 18 UU No 12 Tahun 1995 ayat (1) menjelaskan juga : Anak Pidana ditempatkan di Lembaga Pemasyarakatan Anak.

Apabila mengacu pada pasal tersebut seharusnya Anak Didik Pemasyarakatan tidak ditempatkan di Lembaga Pemasyarakatan Klas I Makassar karena Lembaga Pemasyarakatan tersebut hanya diperuntukkan Narapidana Dewasa tetapi pada kenyataannya disana terdapat lebih dari 70 orang tahanan dan 30 orang Anak Didik Pemasyarakatan.

Pada awalnya di Lembaga Pemasyarakatan Klas I Makassar tidak terdapat tahanan anak maupun Anak Didik Pemasyarakatan. Tetapi anak-anak tersebut berada di Rumah Tahanan Negara Klas I Makassar.

b. Hambatan Dalam Pemenuhan Hak-Hak Anak di Lembaga Pemasyarakatan Klas I Makassar

Ketika berbicara mengenai pemenuhan hak anak di Lembaga Pemasyarakatan sudah tentu sangat berkaitan dengan sumber daya manusia dalam hal ini potensi yang ada pada Pegawai Lembaga Pemasyarakatan Klas I Makassar. Dari hasil data yang penulis dapatkan jumlah pegawai pria sebanyak 104 orang dan wanita sebanyak 19 orang dengan total 123 orang pegawai Lembaga Pemasyarakatan Klas I Makassar. Jumlah pegawai berdasarkan pendidikan yaitu:

1. SMA atau SMK : 59 orang

2. Diploma : 13 orang.

3. S1 : $37 \quad$ orang

4. S2 :14 orang

5. Akip : 8 orang

Berdasarkan data diatas jumlah pegawai yang memiliki pendidikan terkahir SMA dan SMK adalah 59 orang, Diploma (termasuk AKIP) sebanyak 13 orang, S1 sebanyak 
37 orang, S2 sebanyak 14 orang, dan AKIP (Akademi Ilmu Pemasyarakatan) sebanyak 8 orang. Dengan demikian tingkat pendidikan dari para pegawai Lembaga Pemasyarakatan Klas I Makassar menurut penulis sudah cukup memadai.

\section{PENUTUP}

Pemenuhan hak-hak terhadap anak didik pemasyarakatan di Lembaga Pemasyarakatan Klas I Makassar, dibeberapa poin yang terdapat dalam pasal 14 belum terpenuhi dengan baik, seperti :

a. Anak didik pemasyarakatan masih di tempatkan atau disatukan dengan tahanan dewasa, meskipun telah memiliki blok tersendiri khusus untuk anak didik pemasyarakatan tetap masih bersosialisasi di lingkungan yang sama dengan dewasa.

b. Kualitas makanan yang disediakan masih kurang memadai baik dari segi rasa dan kebersihan, dan menu makanan yang di berikan kepada anak didik pemasyarakatan masih disamakan dengan warga binaan dewasa, walaupun telah ada surat ketetapan (SK) pembentukan tim pembina khusus blok anak, berlaku pada tanggal 1 Februari 2014, namun kenyataannya belum terlaksana.

c. Dari segi pemenuhan pendidikan, program pendidikan yang diberikan sering tak berjalan dengan baik, atau tak terlaksana dengan baik, disebabkan singkatnya masa hukuman untuk anak, sehingga anak yang telah berada di luar lembaga pemasyarakatan tak melanjutkan lagi pendidikan yang telah diberikan selama didik di lembaga pemasyarakatan. Kualifikasi keahlian dan pendidikan petugas atau pembina, kadang tak sesuai dengan bidang yang dibebankan padanya, dan petugas yang membina dan memberikan materi kepada anak didik pemasyarakatan juga dibebani tugas administrasi, serta tidak adanya daya paksa petugas terhadap anak didik pemasyarakatan juga mempengaruhi pembinaan keterampilan dan program pendidikan tak berjalan efektif.

d. Pemenuhan dibidang kesehatan masih belum terlaksana dengan baik karena disebabkan oleh kurangnya tenaga medis dan alat-alat kesehatan yang kurang memadai.

Prisonisasi terhadap anak didik di Lembaga Pemasyarakatan Klas I Makassar sangat rentan terjadi, disebabkan anak di tempatkan atau disatukan di Lembaga 
pemasyarakatan yang sama dengan tahanan dewasa, dimana masa anak-anak atau remaja adalah masa mencari jati diri, dan terkadang anak sering meniru apa yang dilihatnya di Lingkungan dimana anak berada, atau dengan kata lain baik buruknya lingkungan mempengaruhi tumbuh kembang dan pola pikir anak.

Yang menjadi hambatan dalam pemenuhan hak-hak anak didik pemasyarakatan yaitu: minimnya anggaran yang tersedia menyebabkan beberapa program pendidikan dan keterampilan tak dapat berjalan dengan maksimal. Kualitas petugas yang kadang tak sesuai dengan kualifikasi pendidikan dan keterampilan, serta minimnya fasiltas dan sarana prasarana yang menunjang pembinaan bagi anak didik pemasyarakatan seperti fasilitas pendidikan, perpustakaan, fasilitas olah raga, serta fasilitas pelatihan keterampilan. Dan kurangnya peranan masyarakat dalam program pembinaan anak didik pemasyarakatan.

\section{DAFTAR PUSTAKA}

Achmad Ali, 2002. Menguak Tabir Hukum (Suatu Kajian Filosofis DanSosiologis). PT Toko Gunung Agung Tbk. cetakan ke-2: Jakarta.

, 2009. Menguak Teori Hukum (Legal Theory) dan Teori Peradilan (Judicial Prudence). Kencana Predana Media Group. Edisi Pertama. Cetakan Ke-1: Jakarta.

Ansori Sabuan, dkk, 1990. Hukum Acara Pidana. Angkasa. Edisi Pertama. Cetakan Ke-1: Bandung.

Azyumardi Azra, 2006. Paradigma Baru Pendidikan Nasional Rekonstruksi Dan Demokratisasi. Kompas : Jakarta.

Barda Nawawi Arief, 2004. Beberapa Masalah Perbandingan Hukum Pidana. PT Raja Grafindo Persada, Cetakan Kedua: Jakarta.

Djisman Samosir, 1992. Fungsi pidana penjara dalam sistem pemidanaan di Indonesia, Binacipta : Bandung.

Dwidja Priyanto, 2006. Sistem pelaksanaan pidana penjara di Indonesia. Refika Aditama : Bandung. 
ISSN 2528-360X

Endang Sumiarni dan Chandra Halim, 2000. Perlindungan Hukum Terhadap Anak dalam Hukum Keluarga. Atmajaya: Jogjakarta

Erma Rajagukguk, 1983. Hukum Dan Masyarakat. PT Bina Bangsa : Jakarta.

Hotman paradomuan Sibuea, dan Heryberthus Sukartono, 2009. Metode Penelitian Hukum. Krakatauw Book: Jakarta.

Karen Lebacqz, 2011. Teori-Teori Keadilan. Nusa Media : Bandung. 